\title{
Family Volunteers as Alternative Future Resources: School Leaders' Beliefs and Practices
}

\author{
https://doi.org/10.3991/ijet.v14i10.10189 \\ Hazar Hekmat Malluhi \\ British Institute of Economy and Policy, London, UK \\ Nayel Musa Alomran ${ }^{(凶)}$ \\ Zayed University, Abu Dhabi, UAE \\ nayel shaker@yahoo.com
}

\begin{abstract}
Schools and community engagement are seen as effective factors for making schools a thoughtful place. This case- study employed mixed methodology to explore the phenomena of parent involvement and to know the exact characteristics of the leadership style in the school. This case study examined and described school leaders' perspectives, attitudes and practices towards parents' involvement in an Abu Dhabi primary school using a variety of data sources including, interviews, open-ended teachers' questionnaires, school selfassessment surveys and mothers' council self-assessment surveys. The findings revealed that the school leaders effectively employ multiple collaborative, shared and transformational leadership practices to improve parent/family volunteering. Teachers and parents have good communications. The mothers' council and the administration enhanced many different parental activities. There are some barriers in parents 'participation like language and the lack of the awareness of important role of parents in the school. The implications of this study revolve around the important roles the school leaders have in helping parents feel supported and encouraging family volunteering. The school leaders have to increase the encouragement of parents' involvement in general and family volunteering in particular. This study is a calling for a shift from random acts of parents' involvement to coherent, comprehensive, continuous, systematic and equitable family volunteering approach.
\end{abstract}

Keywords - Family volunteering, school - family partnerships, family engagement, school leaders, parents' involvement, Collaboration, transformational and shared leadership, and family volunteering.

\section{Introduction and Rationale}

There is a growing understanding of the importance of the relationships between schools and communities in playing a major role in the development of successful schools. Researchers recognize that schools cannot successfully educate children without community support [1]. Community-school engagement is seen as an effective way for making schools thoughtful places for innovations, collaboration, and 
democracy with high standards and expectations. Castro, Chrispeels and Griffith have also stressed the necessity of the role of the community in schools. [2]

Today involving the community and more specifically, parents in school reform is an important research topic. Educators have emphasized the importance of parent involvement in the educational process for decades. Parent-school collaboration has been advocated as a desirable educational goal, in spite of it sometimes beings difficult to achieve. Dombrowsky [3] has shown that student learning and achievement improve when parents play an active role in their children's education and that good schools become even better when parents are involved. "Parents play a vital role in the development and education of their children. Parents and families, with the support of their school and community, have the primary responsibility for the development of their children character. In addition, research clearly indicates that good schools become better schools when they strongly connected with parents as part of the learning community" (p.7)

In the UAE the late Sheik Zayed Bin Sultan Al Nahyan represents a quality leadership style; he called for shared vision in most of his speech "The late Sheik Zayed Bin Sultan Al Nahyan deployed all efforts to set up a foundation to provide a comprehensive environment of education at once modern and future oriented. He considered that knowledge is like a lantern to guide humanity to the right path" [4]. With his vision in mind, leaders of the UAE are working towards reforming education to meet 21 st century demands. Systemic reform in the United Arab Emirates (UAE) is beginning with a strong focus on educational leadership. Researchers and universities in Abu Dhabi in particular are working to identify a standards-based form of educative leadership that would cohere with the needs of the UAE. "Principals in the U.A.E will be expected to implement the reform initiatives through collaborative work planning, participative budgeting, promoting interactive pedagogy, developing extra-curriculum activities, evaluation and community communication, and engaging parent and other community representatives in governance" [5].

Abu Dhabi government and various stakeholders are promoting parent school collaboration as an important way to improve children's academic success. In 2005, the Abu Dhabi Education Council (ADEC) was established, to develop education and educational institutions in the Emirate of Abu Dhabi, implement innovative educational policies, plans and programs that aim to improve education, and support educational institutions and staff to achieve the objectives of national development in accordance with the highest international standards [5]. In 2008, ADEC embarked on an ambitious reform to achieve the sought goals and one major element of ADEC's strategic plan 2009-2014 is to establish an effective line of communication with parents "The government of Abu Dhabi recognizes that an effective education system requires a strong partnership between parents and schools, and will actively seek to involve parents by keeping them informed of their children's progress, encouraging home support in the learning process, and consulting with them on entailed issues" [6]. Therefore, ADEC has moved parent involvement to the forefront of the reforming plan in schools because it considers that the parent involvement is a crucial factor that can help it to achieve its educational goals. 
As Abu Dhabi works to improve schools through parent involvement, it is important to examine how schools and educational leaders are working towards involving parents in the reform efforts.

\subsection{Purpose of the research}

The purpose of this study will be to examine the attitudes of primary school leaders, teachers and parents in an Abu Dhabi public school toward parental involvement. The study will examine leadership style, potential barriers to parental involvement, ways of improving schools' experiences with parents and how these experiences shape the relationship between schools and parents. The study aims to explain how school leaders provide the support needed to connect parents to the school, and to explore how these school leaders enhance parents' participation in the school.

\subsection{Research questions}

Main research question: What steps and practices do Emirati school administrators, follow and take to promote effective parent involvement /family volunteering in U.A.E. schools?

\section{Sub Questions}

- What are the attitude, and beliefs of the school administrators towards parents/family volunteering?

- What are the attitude, and beliefs of the school teachers towards parents/family volunteering?

- What are the attitudes, and beliefs of the head of the mother's council and her assistant towards parents/family volunteering in the school?

- In what specific ways do school leaders involve parents in School?

- What issues and advantages do administrators identify regarding parents/family volunteering in the school?

\subsection{Limitation}

This mixed research (qualitative and quantitative) uses a small sample size. The findings are not meant to be generalized to populations because the research took place in one school in Abu Dhabi. Surveys were developed by the researchers. They were not tested and retested for validity and reliability. Meaning was lost in translation from Arabic to English.

\section{$1.4 \quad$ Literature review}

The theories which can best serve my study goals are the theories of Fullan [7]. Bass[8] and Senge [9]. Fullan [7] served as a guide of collaborative and shared culture. Bass [8] explained the transformational leadership theory and Senge [9] who focused on the fifth disciplines and the importance of shared vision and teamwork in 
the school. These theories are important to my study because they serve as a framework, guide and underpinning the importance of transformational, collaboration and shared leadership in enhancing the parental involvement as an effective strategy to increase student achievement.

\section{Leadership perspectives:}

Transformational leadership: Globalization, new technology, and changing social patterns have significantly disrupted the education sector over the past decade. Transformation has become a necessity for education systems to improve the students' performance and match them to the demands of $21^{\text {st }}$ century. Bass [10] defined transformational leadership in terms of how the leader affects followers who are intended to trust, admire and respect him. He identified three ways in which leaders transform followers through increasing their awareness of task importance and value, getting them to focus first on team or organizational goals. Bass [11] provides a framework and foundation for managers and leaders in human services organization to develop a contemporary approach relative to the roles, relationships, and resource capacities that drive their professional positions and sustain the respective institutions. In other words; he means that transformational leaders call for positive role modeling and inspiration. He indicated that transformational leadership has a positive effect on work attitudes and performance at both the individual and organizational levels Bass [12].

Fullan [13] considers transformational leadership to be important because "topdown change does not work. People resist when leaders try to tighten things up" (p.35). As well as Northouse[14] who consider Transformational leadership is a process that changes and transforms individuals. He states that in 39 studies of transformational literature, individuals who exhibited transformational leadership were more effective leaders with better work outcomes. Díaz-Sáenz, [15] stated that transformational leadership is one of the most researched, studied, and debated approaches to leadership. It also has more influence than any other leadership approach on the organizational leaders of today. Gumusluoglu \& Ilsev [16] urges that people need to be highly creative and innovative in order to succeed in the transformational process in their organization. In the light of current educational reform, the traditional role of principal is changing to the role of "transformational" leader.

Therefore, in the Middle East, educators have recently begun to examine and restructure their educational systems and practices. Abu-Tineh, Khasawneh,\& Al-Omari [17] stated in the findings of their article that Kouzes's and Posner's model [18] is being moderately and successfully practiced by Jordanian school principals. Posner's Transformational Leadership Model provides school principals in Jordon with practical guidance on how to lead, as well as practical suggestions on how to act during reform agenda.

On the developmental aspect, the transformational leaders increase the followers' autonomy and encourage them to think independently and critically. They raise their level of self-efficacy, self-confidence, and competence (Anderson, Gisborne, \& Holliday [19], Anderson, [20]. In brief, transformational leadership is the leader's ability to increase organizational members' commitment, capacity, and engagement in meeting goals (Chew \& Chan) [21]. 
Collaborative leadership: Collaboration is an important feature in the management of schools. Fullan [7] supports the collaborative learning cultures, and its effect on school system. He discussed the topic of school change and analyzed the concept of tri-level reform school, district, and state/national levels that working together in collaborative and shared leadership to build and strengthen capacity to achieve meaningful change. Boaduo, \& Adjei [22] acknowledged that there should be some collaboration policy in the school to be able to achieve set objectives and better performance for both teachers and learners. Masumoto\& Brown-Welty [23] mentioned that the findings of their research showed that educational leaders in the three schools studied with the highest poverty rates and highest percentages of English Language Learners made significant improvements in student achievement through active involvement of parents and the mobilization of other external and community resources.

Shared leadership: Many educational leaders, especially principals, often find themselves isolated and alone, believing that they are, primarily, responsible for leadership in their schools. Such a stance constitutes a very narrow view of leadership. Principals, especially, need to be secure enough in their own identity to freely share and distribute leadership responsibilities among teachers and other key stakeholders. In this way, they are more likely to create school cultures where key stakeholders, especially teachers, students and parents, willingly take responsibility for the leadership of their school community. Such a shared approach to leadership in schools is receiving strong support in the literature on educational leadership. Chrispeels [24] defined the shared leadership in her book Learning to Lead Together as "principals, teachers, support staff and some community members and students, who come together in leadership teams, governing bodies, or committees to jointly make decisions required to manage the school and improve the learning environment"(p.5). She addresses how principals and their staff struggle with the challenge of shared leadership, how they encourage teacher growth and development, and how shared leadership can lead to higher levels of student learning. She showed how the principal has to make turning points to empower his staff to make decisions in the school with collaboration of parents. Senge [25] focused on the necessity of the shifting from individual vision to shared vision, because he considered that in shared vision people understand their role in the larger whole, support one another, and learn from mistakes.

Regarding the concept of shared leadership Kouzes \& Posner, [18] figured that leaders cannot do the reforming alone. Leaders need the help of others. That means principal needs the efforts, and the opinions of parents, staff and administrators to fill any gaps in the school and overcome the obstacles that constrain the reforming policy. However, other studies have shown that a real change could be happen if all stakeholders work together to face the educational field's problems. According to school restructuring Nsubuga, [26] suggested that if leadership is expected to have a pronounced effect on education, it must be visionary, transformational and shared, because shared leadership helps to establish a mutual beneficial cooperative system between administration and parents, which leads to shared benefits for all stakeholders.

Effect of Leadership on Student Performance: Educational leaders have to create the effective learning environment to enable the students to maximize students' poten- 
tial to succeed in school and throughout their lives. In other words, successful school decision and wise educational leaders protect their school environment, and encourage active participation and partnerships with all members of the school community. This is because a successful school requires interaction and joint responsibility from everyone in order to use the talents of its leaders and teachers, and to engage the students and their communities. Foster [27] investigates the ways school improvement, meaning the enhancement of student learning, is generated by principals and other school members. The findings are that competent administrative and teacher leadership contribute to school success. In addition leadership is found to be a shared social influence in positive change. Supporting this idea, Sergiovanni [28] argues that educational change is more about improvement rather than reform. He describes four interacting units of change: Individual, workflow, school, and political system. He suggests that change should facilitate teamwork to achieve the desired goals.

Advantages of Parent Involvement: Parental involvement within the schools has changed dramatically throughout the last century and the education of the children becomes not the sole responsibility of schools but collaboration between parents and schools. Parents are a key component in the field of education, and concerning the importance of parent's participation. Christianity was the first to call for the parental role in education. Official Church teachings and documents affirm the importance of the home-school relationship in Catholics (Catechism of the Catholic Church, 1999, \$2225) [29] later on Islam deemed education to be a must to every Muslim, and urges parents to take care of their children's education. (Holy Qur'an, Ta-Ha 20:114) [30].

The literature has revealed parental involvement as an effective strategy that shows positive effect on student achievement. Castro, Chrispeels and Griffith [2] described in their research findings that family practices may strengthen the incidence and effectiveness of parental involvement across varied school communities. Families' involvement in children's education takes a variety of forms, including involvement in the home (e.g., help with homework), involvement in the school (e.g., attending open houses), parent-teacher communication, and parent-to-parent communication (Dearing, Kreider, Simpkins, \& Weiss, [31].

Previous researches showed that parent involvement leads to student achievement (Jeynes,[32] Midraj,[33], Jeynes, [34] Colarusso \&O'Rourke, [35] Mo and Singh [36] Kochanek, Wraight, Nylen, and Rodriguez, [37]. The relationship between parent satisfaction with their children's school and school choice seems intuitively obvious and some parents evaluate their children's school on a number of variables including teachers, administrators, curriculum, technology, facilities, involvement, transportation, and budget. These variables may influence the parents' satisfaction with their children's schools. The parents' satisfaction can lead to effective volunteering. Some studies have explored what constitutes parental school satisfaction Friedman et al., [38] presented a questionnaire that measured 15 areas of parents' experience with their children's school. Their questionnaire contained 87 dichotomous response scale items. The questionnaire included items that covered facilities and equipment, computer technology, school bus, school communication, parental involvement, teacher effectiveness, teacher communication, board of education, superintendent and central 
office, principal, curriculum, training, and school budget. The model was based on their own previous work (Friedman et al,[39] .

Parents' involvement became an additional valuable component of schools' resources. For example: For PISA in 2009 parents in some participating countries were given a questionnaire to complete and their responses were analyzed alongside those of students and principals. In these countries, a strong correlation was found between parental involvement with their child during primary school and the child's reading performance at the age of $15 \mathrm{Al}$ Sumaiti,[40] .

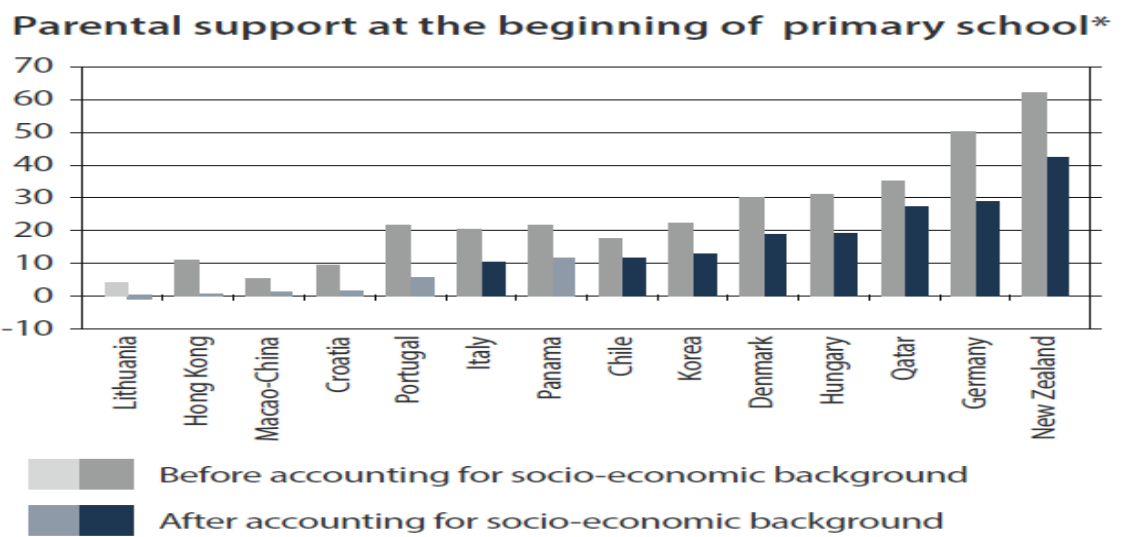

Fig. 1.

As can be seen in the graph on the left, students whose parents reported that they had read a book with their child "every day or almost every day" or "once or twice a week" during the first year of primary school scored higher than students who had parents that stated that they "never or almost never" or only "once or twice a month" read a book with their child. Dubai's regional neighbor, Qatar, had a very high score point difference in comparison with other countries for this question and other questions relating to parental involvement, suggesting that students from the Gulf region, including Dubai, have a culture where they would significantly gain from enhanced parental involvement. OCED [41]. In other results from the OECD's Program of International Student Assessment PISA in 2009 shows that the involvement of parents has an obvious significant effect on their children. This involvement is not limited to direct involvement in learning activities at home but also includes a range of other activities including reading, discussing how well children are doing at school or even the simple matter of eating main meals together. A thorough search of the research literature revealed that, no studies are directly associated with the parents volunteering in U.A.E government schools.

Teachers' Attitudes towards Parents/Family Volunteering: Traditionally, school systems have struggled with how much power and influence parents should be allowed over school decisions and teachers relationships with parents. Mostly they were frustrated by the parents who choose not to be involved. While recently, there have been discussions among parents and teachers as to the importance of each party's role. 
For example: The parent education movement began, mainly through the establishment of parent-teacher associations (PTAs) in the United States. These associations established different training courses for more awareness about the importance role of both parties.

Keeping parents out of schools can create the false impression that schools run smoothly, which in turn can have costly effects, such as making parents more hostile and denying teachers the chance to acquire knowledge and to gain the parental support that makes schools work better for their students. Teachers should be called on to examine and reflect on their own beliefs, especially any preconceived notions that may be detrimental to encouraging parent involvement. On the other hand, teachers' assignments should create family-friendly environment for home-school encounters; home-school communication; expanding the definition of parent and community; innovative volunteering and getting results Eleanor\&Lemmer,[42]. The two-way communication occurs when teachers and parents dialogue together and effective dialogue can leads to better student performance Anfara and Mertens, [43].

Barriers to Parent Involvement: There are several barriers to parental involvement in schools. Some parents may feel their participation is not necessary considering their children are doing well in school, and others may have no history of being involved and see no reason to begin doing so. Many parents may have had poor experiences which prevented them going through school. Others might have encountered academic difficulties or other painful experiences during their time in school. The role of the principal could be a barrier to parent involvement. The principal has a pivotal role in establishing a foundation to bring about individual school changes and successes. The principal's ideas and actions can provide the financial support as well as the motivation to elevate the professionalism and morale of the teachers and bring the entire school staff and faculty into the process of promoting strong parent-schoolcommunity partnerships.

Minke and Anderson [44] mention the importance of empowering parents to encourage them to be advocates for their children. Lack of encouragement could be a very important barrier. A supportive relationship between parents and professionals is a key element in parent involvement.

Related literature in U.A.E: School and systemic reform in the United Arab Emirates (UAE) began in 2006 with a highly critical evaluation of the national system of schooling to improve it, to prepare students for an active role in a modern knowledge society, and to match the educational standards of $21^{\text {st }}$ century demands. Research which has been conducted in Abu Dhabi by Macpherson, Kachelhoffer,\& El Nemr [45] reveals that the Ministry of Education, which is highly centralized, has no clear vision and suffers from job inflation. School principals need intensive training and continuous follow-up support if they are to lead the reforms. "The Education Departments in each geographic zone are, in general, dysfunctional" (Macpherson, Kachelhoffer \& El Nemr, [45] But the reforming process which started 6 years ago focused on capacity building, systemic educational reconstruction and boosting leadership capacities in school communities. Therefore, the reform policy of the school that includes improving the principal leadership perspectives is helping to allow parents to participate in school to share in the educational development. According to Rabaa Al- 
Sumaiti [46] students with parents who are involved in their school tend to have fewer behavioral problems and better academic performance

In Dubai the GEMS Parental Engagement Program was launched in 2009 with the goal of improving student achievement. A priority in every GEMS school, this initiative requires strategic and on-going support of parents to help further student progress. Demand for the program, is evident by the tens of thousands of parents participate in the Parental Engagement events and activities in those schools. Schools facilitate regular opportunities for parents to understand the value of engagement and help develop their skills to assist learning at home. GEMS ensures the school infrastructure and professional development to integrate parents into teaching and learning, and provides information, tips and resources on both parenting and how to support the ' 3 a-day' approach at home, on a dedicated Parental Engagement website. (Gems Royal Dubai School, [47].

In Sharjah, Dr. Sheikha Al-Taneiji [48] conducted research on students' views on parental involvement in United Arab Emirates. Her findings from a survey of 7,287 parents from 209 schools in 3 school zones (districts) across the Emirate of Abu Dhabi for the academic year 2009-2010 indicate parental involvement in schools is one of nine factors identified as predictors of parents' satisfaction with subjects taught in their children's school in Abu Dhabi. These school factors are teachers and teaching, parents' participation and involvement, assessment and reporting, communication, school facilities and resources, overall effectiveness, and school environment and support services. This example is an evidence of the educational reform policy in the U.A.E which involve the community and especially parents to share in the new learning process.

Moreovere, H.H. Sheikah Fatemah bint Mubarak, Chairperson of the Family Development Foundation (FDF), and the U.A.E General Women's Union stated volunteering in U.A.E has an important position at the institutional and individual level. She stressed the importance of bringing children up in a moral and social way, referring to the part played by the family and school in heightening values of sacrifice and developing teamwork goals which reflects positively on students' outcomes. Many leaders in the U.A.E. support researchers and try to enrich the educational fields with useful results. "The government aims to help create an environment that fosters innovative research and development through incentives that include funding. Incentives will be used to encourage partnerships between the private sector, research institutions, and universities" (ADEC, [6].

Consequently, I decided to conduct this about family volunteering to fill the gap in the literature of U.A.E. because there is very little literature on parent volunteering. An examination of the literature which is available demonstrates that there is very little parent volunteering in schools. I think the parents volunteering are part of the educational reform process and the literature review of the U.A.E reveals that Emirati families need more participation in schools. In addition, there is a strong demand for the volunteering culture in the educational field and a lack of studies in this area.

Similar to the literature written in the US, Currie and Al Sharif [49] found that close ties between home and school can increase student achievement. Ross Currie and Fareeda Al Sharif' [49] wrote an article about the advantages of closer ties be- 
tween home and school and how this relationship can increase the students' progress. Ross Currie and Fareeda Al Sharif give many examples of Dubai schools like Al Ibdaa School and Dubai program for mothers. This program (Dubai program for mothers) teaches the mothers by the teachers how to help their children, especially with their reading. Another example is Amna Secondary School in Dubai. This school is always inviting mothers to attend classes when their daughters are presenting something. That means the new policy of educational reform could enable parents to have active and effective roles. As Badri, Mason, \& El Mourad, [50] believe that the most significant school factors relate to satisfaction with parent participation, reporting and assessment, and curriculum.

Summary: The literature reviewed in this chapter explores five main parts of leadership perspectives, effect of leadership on student performance, effective role of parents in schools (parental leadership), the role of teachers towards parents/family volunteering, Strategies for improving parent involvement, and the barriers to parent involvement in schools. The literature showed that principals who can hold and practice transformational, collaborative and shared leadership qualities can foster capacity development and bring higher levels of personal commitment amongst "followers" to organizational objectives. Many research studies acknowledged that leadership behaviors make a difference and affect the students' achievement. In addition, the relationship between parents and teachers can also reflect positively on the students' performance. The literature review showed some barriers to parent involvement/volunteering like past poor experiences of parents with schools, language, social problems, and lack of trust, lack of encouragement and communication and financial issues. The U.A.E, government started in 2006 to pursue a comprehensive policy of educational reform and one of its main standards is promoting families' communications with school.

\section{Methods and Procedures}

The purpose of this section of the study is to describe the background and context. Both the qualitative and quantitative methodological approaches were employed to collect and analyze the data.

\subsection{Research design}

A mixed- methods case study was utilized to collect and examine the data and answer the researchers' questions. Case studies are suitable for exploratory, descriptive and explanatory research Yin [51]. A mixed methods study is defined as a design in which mixes both quantitative and qualitative approaches Tashakkori \& Teddie,[52]. This study uses exploratory mixed methods which means that the study is heavenly qualitative than quantitative Creswell [53]. I collected interviews, qualitative teachers' questionnaires, observation and documents review data. Then I used school and mothers' council self-assessment surveys to collect quantitative data. The case study method helped me to explore the phenomena of parent involvement/ family volunteering 
and to know the exact characteristic of the leadership style in the school. Through a case study, a detailed contextual analysis of a limited number of events and practices can be conducted in the school. According to Yin [51] the case study research is an all-encompassing method covering design, data collection techniques, and specific approaches to data analysis. I choose to collect both qualitative and quantitative data to provide better understanding and comprehensive analysis of the research problem (Creswell \& Plano Clark, [54]. Mix methods can be useful for more investigation, more truthfulness and richer information. Triangulation in time, space and person can also illuminate some ways to test or maximize the validity, reliability, accountability and truthfulness of the mixed case-study.

\subsection{Background and context}

Setting: This study took place in a public primary school in Abu Dhabi. It sheds light on school leaders' perspectives, attitude and practices, towards parents'/family volunteering in school. It describes the relationship between parents/family volunteering and the school leaders' leadership policy in the school. The school was selected due to its active family engagement program. In the school, the students received the first stage of education from grade one to six. The school services approximately 800 students and has 34 classrooms. Upon entering the school, the first things to catch your eyes are the pictures of students with a touch of Emirati traditions and culture. Many drawings are made by the students themselves. These drawings give the school a positive environment and show the creativity of the students. In the playground the vision, mission and goals of the school are written on big boards on the school walls.

All staff members seem to work and interact well with the students. I saw this during morning assembly where every teacher walks around her class smiling and happily doing exercises with them. The furniture in the school matched the educational purpose. The school has two computer labs, a library, a science lab, and two big swimming pools.

Mothers' council: The Mothers' Council office is located at the back building of the school. It was established in 2007. The main goal of the mothers 'council is to facilitate parents' involvement in their children's education and resolve educational or behavioral problems among all parties. Moreover, the council offers programs for parents, teachers and children together. The services and the programs are flexible and family focused. The council provided parents with the opportunity to talk informally with their facilitators. The facilitators are the parent volunteers who work in the mothers' council to organize and offer help to other parents, and to update the current information. The time table of the council was from nine to one o'clock two days a week only. The funded is collected by some parents' charity and a little budget from the school.

Participants: Participants in this study were five school administrators (the principal, two heads of English, math and science and the head of the Mother's Council and her assistant). In addition there were thirteen teachers who answered a questionnaire. Eleven teachers were from different countries like Canada, Australia, England, South Africa, and Egypt. The ages of the teachers are between 35 and 43 years. Their years 
of experience teaching range from seven to fifteen years. Other participants were thirteen mothers who are members of the mother's council and the staff of the administration who work with the five school leaders such as the two secretaries, three social workers, and four heads of different departments. These sample sizes were appropriate for my study because they provided enough data to help me explore my research questions. The names used are not the real names of the participants.

The principal of the school: She is Emirati and married. She graduated from Zayed University holding Master degree in education. She has a strong desire to effect change in her school and reinforce the parents' relationship in the school.

Heads of department: The other interviewees are the two heads of English, Science and Math. One is 45. She has been a trainer of teachers for 18 years. The other one is 53. She is the second head of English, Science and Math.

Head of mother's council: She is 33. She is a married lady with four children. She was working at the Abu Dhabi Securities Foundation. She offered to work as a volunteer in her daughter's school. The administration of the school asked her to be the head of mother council due to her education, volunteering efforts and self-confidence and her strong willingness to serve.

Assistant of the mothers 'council: She is 38 married with five children. She was an accountant. She enjoys volunteering and she is very active and helpful.

Thirteen participant teachers: All teachers of English, math and science from grade one to grade five.

Thirteen participant mothers: They are the volunteering members of the Mothers' Council.

\subsection{Instrumentation}

The quantitative portion of the study consisted of the Mother's Council self- assessment survey and school administrators' self- assessment survey, while the qualitative portion of the study was comprised of interviews with the five school leaders, teachers' open-ended questionnaire, and observation and document review (see Appendices A, B \& C).

Data collection: The data were collected through using multiple sources to establish the meaning of the parents/ family volunteering from the view of my participants. Data for this study were collected mainly through in-depth and structured interviews with five of the school administrators; each interview was between one to two hours, audiotape and transcribed. The preliminary phase of data collection began after approval was gained from ADEC to have the access in entering the school. Then I handed a consent letter to every one of my participants telling them that their responses and their identities will be kept confidential and that I would not share the information that I obtained with anybody else and the results will be used for academic purposes only.

Five school leaders' interviews: I interviewed the principal because principals can play critical roles in the development of high-quality schools EdSource, [55]. In conducting my interview I followed the common information found within the literature relating to interviews, according to Creswell [56]; [57] which includes 
- The preparation for the interview

- The constructing effective research questions

- The actual implementation of the interview(s)

In addition to that Merriam [58] stated that interviews are necessary to obtain participant language and voices about the topic they are used to gather information on the subject of individual experiences, views and reactions.

The interviews with the participants' mothers and school leaders were useful for triangulation of data obtained from school sources and helped to increase validity (truthfulness). All interviews began with an explanation of the importance of the voluntary participation, an overview of the general purpose of the study, and an introduction about me. Interviews were digitally recorded. There were 14 interview questions with some sub questions. The interview questions described the leadership style, traits of an effective principal, and critical issues of parents that prevent the involvement in the school, effective strategies in developing relationships with parents and the specific steps to increase parents' opportunities to volunteer in the school. The same questionnaire (or interview protocol) was used for all the interviewees.

I started first with the principal interview, and interviewed the other school leaders to obtain their perceptions, perspectives and voices about the topic. The interviews of the head of the mothers' council and her assistant were in Arabic.

Open-ended teachers' questionnaire : I distributed open - ended questionnaires for teachers in English. They consisted of thirteen questions focused on their thinking about leadership styles and the policy of the principal and her practices in the school. Additional questions included questions were about the teachers' attitudes towards the parents' involvement in the school and their strategies they used to encourage parents/family volunteering. The purpose of this questionnaire was to approach the problem and examine the phenomena from different sides. Thirteen teachers completed open-ended questionnaire packets during one week. The questions asked in the instrument were about perceptions towards parents'/family volunteering, the best things about working with parents, challenging issues, school communication with parents, and the most and least effective methods of involving parents in schools. I held a meeting with the heads of the department to help me to distribute and collect the teacher questionnaires.

Self-assessment survey: In addition, I developed the questions of the administration self- assessment survey and mothers' council self - assessment survey to help me answer my research questions. They were distributed in two languages (Arabic and English) to develop a better understanding of parent involvement in the school. The purpose of the two surveys is to measure the practices and the level of encouragement in the school towards parent involvement. They consisted of 14 questions describing the school practices towards parents. For the Mothers' Council self - assessment survey, I held a group meeting to explain the purpose of the survey and asked them first to read the consent letter and sign it, and then fill in the survey. Then I distributed the survey and let them answer it individually. The same procedures were repeated for the administrators' self -assessment survey. At the end of the survey there was an open- ended question about reasons for mothers' volunteering at the children's school. 
It measured the practices and the level of encouragement of the school towards parent involvement on a small scale. There are limitations on the use of using a selfdeveloped questionnaire. Questionnaires do not tend to reveal the underlying reasons for responses, why and how a person gave that response. The instrument has not been tested for validity and reliability.

Observation: I decided to observe the activities and the practices of the principal in the school by writing daily field notes and photocopying many files from the Mothers' Council archive and by taking photos and recording videotapes. The purpose of my observation was to approach the problem from different sides and opinions. Writing the daily field notes lasted for two months and took three hours daily from 9:00 am to 1:00 pm. Observations were made of the principal in action during formal events such as staff meetings, board meetings and advisory meetings as well as observations of interactions with students, teachers and parents in their daily activities.

Document review: I collected documents from the Mothers' Council files, administration documents, and social worker records in addition to taking some photos and recording some video tapes for some occasions like some activities in the morning assembly. I made some photocopies and wrote notes on them. Documents reveal what people do or did and what they value. Additional data came from school newsletters, web sites, the school face book account, and some informal mother's interviews.

Data analysis techniques: To analyze the quantitative survey of school and mother self- assessment, I used the excel program, while the qualitative data were collected through the five interviews, teachers open-ended questionnaire, observation, and document review. Following Patrick Love's [59] researches, that the qualitative data were coded for emerging themes and patterns. I recorded all the interviews using video tape to achieve more accuracy. "When a qualitative research design involves the collection of audio taped in-depth interviews or focus groups, researchers must decide whether their analysis is best supported by transcription or by researchers' notes derived from or supplemented by a review of the audiotapes" (Patton [60] "Multiple types and sources of data are necessary for a school leader to understand a school's strengths and weaknesses, set priorities for improvement, concentrate change efforts, and establish a baseline from which to monitor progress" (Guthrie \& Schuermann [61]

According to Opdenakker, Raymond [62] face-to-face interviews can take its advantage of social cues, such as voice, intonation and body language. They believed interviewees can give the interviewer extra information that can be added to the verbal answer of the interviewee on a question. This helped me to collect interview data and to determine any themes or patterns within the interviews to explain the five administrators' perceptions of parents linvolvement in the school.

The data obtained from interviews were evaluated by using the descriptive data analysis which is a technique of qualitative data analysis methods. After analysis of the data collected, coding and emerging themes with a focus on their role and strategies to promote parents involvement in the school. This process allowed for further grouping of related information from various participants to answer the research questions. 


\section{$3 \quad$ Major Findings}

\subsection{Theme 1}

The school Leaders' practice transformational, shared and collaborative leadership style towards parents/family volunteering in the school.

School leaders' practices and beliefs

The principal: I realized that the principal has good responsibilities towards the school. She spent the most of her time on administration's activities, such as managing and fulfilling the students', teachers' and the parents' needs. On the other hand I found the principal's time was used to manage and support internal relations, such as developing relationships with students, teachers and staff. She also was managing the external relationships such as following ADEC supervisor's comments and meeting the students' parents. She motivated teachers and students, identified and articulated vision and goals, developed high performance expectations, and fostered communication through her improvement plan. For example: ADEC wanted the principals to enhance the policy of continuous professional development among teachers, especially the new joiners in the school. The principal established a professional development center in the school, focusing on IT programs and new teaching methods.

Another example: The principal supported the relationship between parents and school. The principal has good relationships with parents. She appreciates the Mothers' Council performance in front of all staff using different ways like announcing in the morning assembly news, end of year presentations and thank you certificates and different ways of communication.

The principal established a SIP plan (School Improvement Plan). The plan focuses on specific goals and strategies for making changes in the school. The SIP is a good example of the transformational leadership policy. She shared with others in her decision making because she established a decision- making team, the members used analytical thinking skills, towards the results and evaluated objectively to prepare the needed detailed plan. The principal showed me the School Improvement Plan file and pointed out the section pertaining to increasing parent involvement strategies in coming years.

My observational data allowed me to combine depth and breadth in examining and observing the principal's behavior during the month. The observation helped me to see and hear events that the principal takes part in, what kind of leadership model she is following and to compare her words to her action. The principal collaborative leadership style is reflected in her practices. I noticed the principal's collaborative leadership style through the comments and the opinions of the teachers on the principal's character and personality. They talked positively about her service and humility. She encourages all the teachers to work with parents because she believes that schoolparent collaboration is necessary for the desired outcomes in a child's education (Levy, Kim, \& Olive, [63].

The head of the science and math department: She is a democratic leader. She discusses the new projects with teachers before she asks them to implement them. She respects others opinions and the teachers call her a good listener. 
She conducts several professional development workshops for the teachers to improve their teacher leadership qualities and instructional methods.

The second head of science and math department: She seems to have a strong personality. I gained this impression due to some of her teachers' comments and through my contact and dealings with her. She leads the teachers to follow the rules in strict ways. However, she supports the parents' involvement in school and she had an effective role during open day. She sent invitations to mothers to invite them to attend and share as volunteers in traditional food, sweets and henna, I saw that in the administrational files.

Mothers' council leaders: The head of Mothers' Council: She is a real openminded leader. She told me in her interview how she did her best to change some negative opinions of the parents at the end of the open day activities and how the parents were interested in joining in these activities. Through my observation I found her very active. She is always busy. She has many positive relationships with the social workers in the school. She always communicates, finds solutions, brings the personal information of the students' parents and collects the needed data from them. For example: she found one time that the low performing students did not have good parent communication with the school. She visited some of those students' houses to encourage the mothers to increase their involvement in the school to follow up and to observe their daughters closely.

The assistant of the Mothers' Council: She is a very cooperative mother. She talked in detail about many offers and efforts coming from the parents like sending vouchers for new furniture and good quality watches for teacher day awards. She is active and I saw her when she distributed numbers to all visitors and parents to join in school raffles to add sense of fun and suspense among parents during the National and Open days.

\subsection{Theme 2}

Offering opportunities to volunteer: Analysis of the interviews reveals that the school leaders have different specific steps to increase parents' opportunities to volunteer in the school and by different ways. As the following:

Parents 'survey: Led by the principal, the school administrators distributed many activities like a parents' survey which helped her to collect very important information about parents to help in decision making later on.

School-home project: She rewarded a teacher who established a new project. It was a school -home project which provided training courses for mothers in the school under the supervision of teachers of different subjects. The goals of this training program are to teach mothers about new teaching methods and project-based approaches. It was very effective because it makes good connection among, students, teachers and parents. The parents in this project come to school and sit in a specific area which is prepared by the class teacher. The class teacher trained the parents on how to help their children in research assignments and how to deal with project based approach. The principal emphasized the good results of that project. A Harvard Family Research 
Project (2005) emphasized on the importance of increasing the effective strategies to strengthen the relationship between home and school.

Parents as substitute teachers: Another step to increase parent's involvement was parent- teacher substitution. The principal gave an example of one parent who had a certificate in science and history that was able to substitute for an absent teacher for a week. The principal took a quick action and asked the approval of ADEC because the time was very critical. Another example was a father who is an athlete offered two hours practicing after school for overweight students. They were sessions for teaching a healthy life style. When a mother complained about the repeated absence of certain teacher due to her continuous sick leave and the Council with a cooperation of the administration and the permission of ADEC, nominated a well-educated mother who has the same certificate in social studies. This mother worked for one month in a very smooth and successful way.

Flexible means of communications: The principal and the assistant insisted on the flexibility for meeting times among teachers, administrators and parents. The principal put in the reception hall of the school a list of the teachers emails and the free periods of the teachers to help the parent find chances to meet their children teachers. she said, "School must reflect welcoming and trustful environment to encourage parents to feel that their contributions are appreciated."

\subsection{Theme 3}

Positive teachers' attitude towards parents' involvement. They have a good relationship with their students' parents, and they work collaboratively together.

After analyzing the answers of the thirteen teachers' open-ended questionnaire, I found that the teachers believe parents are a great resource who should be used more in schools. They stated parents should be encouraged to volunteer and as much as possible.

\subsection{Theme 4}

Positive school climate. Teachers show job satisfaction which reflects positively on the school environment and students' performance.

Job Satisfaction: From the analysis of my results, I found that the school climate is mostly positive. I felt the school was running smoothly. Most of the members inside the school were working with the spirit of teamwork and enthusiastically.

I revealed that, the school leaders and the teachers informed parents about the electronic communication system that has ADEC provided and facilitated to enable the parents to update the news of the school. That makes the parents so happy and satisfied her new reform procedures. Teachers also pointed out that the new system will resolve many problems and reduce the pressure during the school time. They considered working in this school to be enriching experience. 


\subsection{Theme 5}

The effective role of mothers. Parents are as a vital resource: The participant teachers believe that parents are a vital resource in the education and learning process of the child. With the help of parents, teachers can match community contributions with school goals and integrate child and family services. Parents can tell teachers a lot about their children. Parent contributions enrich the curriculum with valuable comments and practical points of view which will help the school and teachers to provide a program that meets the children's' interests. Moreover, The Mothers' Council members showed a willingness to volunteer while the results of the surveys showed low levels of parental encouragement. Teachers and administrators praise the role of the mothers, in the council, but they asked for more strategic plans especially in increasing the number of the families' volunteers.

The Mothers' Council members didn't have enough sessions to advise the parents to help their children in and out of the class. They scheduled plays, concerts, games, and other events at different times of the day or evening in collaboration with the school to encourage parents to attend some activity sent many certificates of appreciation to thank parent volunteers, but they didn't resend emails to non-participating parents. In general, Parents are satisfied and perform many volunteering deeds but they need to be more organized with better encouragement to offer more and perhaps different types of volunteering.

\subsection{Theme 6}

Parents 'involvement has some barriers such as language, lack of time, misunderstanding and ignorance of the new reform plan: The five leaders, teachers, and parents mentioned some critical issues involving parents in the school. One of them is language. The English, science and math teachers are English native speakers. They lead to a gap in communication and miscommunication and misunderstanding with Arabic parents because many parents cannot speak English and translators are not always available. Also all the foreign teachers cannot speak Arabic. This problem sometimes prevents the parents from coming to school. One teacher complained from the longtime of meeting between translator and the mother. They resist meeting with teachers to avoid embarrassment (Hill \& Taylor, [64].

The barrier of the time was important in previous years when the teachers were not given time to meet parents. Another issue is the ignorance of the reform plan. Rarely, the principal held many workshops and conferences clarifying the vision, mission and the strategies of the school. This is not enough because every year new parents join. This step has a big effect on parents' reaction.

In addition, the lack of commitment from some uneducated parents and lack of responsibility from others are other barriers to parent involvement. Some parents do not like to take the responsibility for helping their children and leave this task to the teachers. 


\section{Discussion}

The findings revealed that the participants' school leaders partially, employed multiple collaborative, shared and transformational leadership practices to improve parent volunteering. Teachers and parents have good communications, the Mothers' Council and the administration enhanced many different parental activities but they did not encourage parents enough to increase the involvement in the school. There are some barriers to parents' participation like language, time, and the lack of awareness of the new reform process introduced by ADEC.

\subsection{School leaders' attitude and activities}

In this section I will highlight how my research reflects, differs from and extends current knowledge of the area in which I have chosen to carry out the research. I found some evidences to support the policy of the school leaders' attitude, beliefs and the activities towards parents' involvement in the school. Obvious indicators show the principal's transformational leadership style: she facilitates change through adapting the transformational leadership theory in her practices. The other four leaders were following the shared and collaborative leadership style to support her reforming policy.

Firstly, the transformational leaders raise the level of the self-efficacy, selfconfidence, and competence of their followers (Anderson, Gisborne, \& Holliday,[19]. It was very clear that the principal worked partially on professional development training to improve the relationship with parents Fullan, [65] and as Marzano, Waters, and McNulty [66] stated that the characteristics of transformational leadership on individual consideration and intellectual stimulation.

The principal developed and circulated a parent survey to find out their opinions and comments to analyze them, identify problems, find solutions, and to provide them with the suitable opportunities for involvement in their children's education. ( Barbuto, [67]\& Spreitzer, Perttula \& Xin, [68].

Secondly, she sometimes collects classroom information on student achievement and uses this information in discussions with teachers about adjusting and improving their teaching strategies and ensures that this information is also used by those developing the school improvement plan. She attends all school council committee meetings and she meets many parents and other community members in her office to listen to their complaints to exchange ideas and possible suggestions and solutions. These actions demonstrate her beliefs in the refers to the importance of shared vision and team work Senge, [9].

Thirdly, she mentioned in her plan that she will give the opportunity for the teachers and the parents to join the decision- making committee and evaluate teachers' performance through answering a teachers' appraisal questionnaire. Giving this opportunity to the parents to share and convey their points of view, will help improve the learning process in the school because when teachers know that their teaching methods will be evaluated by parents in addition to school leaders and supervisors, they will work hard to gain a high quality standard and acceptance. Westmorel, Ros- 
enberg, Lopez \& Weiss [69] believe that the sum of each individual contribution will take the whole group to a higher level.

She considered that the school administrator should be an educational leader who promotes the success of all students by collaborating with families and community members, responding to diverse community interests and needs, and mobilizing community resources (Macpherson, Kachelhoffer ,\& El Nemr, [5].

In addition, the principal planed in her reforming about the necessity of the reform in Emirati schools. As some inspectors in the U.A.E have also observed that the practice of parent volunteers working alongside children in the classroom is not as prevalent in Dubai compared with overseas." Al Sumaiti, [40].

In this school, the principals, teachers, Mothers' Council, and parents work as a team to establish priorities, set goals for improvement and implement strategies to achieve those goals.

\subsection{Positive psychological environment}

The results of the teachers' open-ended questionnaire support these ideas when some teachers stated that the results of their students changed when their fathers attended their classes during job week. The positive school climate helps the relationships of teachers and parents to work together to achieve the same goals for their children who are getting an education for lifelong learning (Caspe, [70]; \& Anfara and Mertens, [43]. The administrators created good relationships between parents and teachers through distributing emails and the telephone numbers to all the families of the children.

In the Mothers' Council self- assessment survey, all the participant mothers stated that the teachers had positive attitudes towards parents. One teacher told a story about group of teachers and mothers who created an account on Face book this year to keep members current about events and issues occurring in the school. .

Above all, school administrations believe that the parents can take some responsibilities and fill some gaps in the school. Teachers' problems will reduce when they have good relationships with parents. For parents, the school leaders believe that it is $\mathrm{s}$ a good opportunity for them to know more about their own children and how they can help them. For students, I think one of the major benefits is the gain in confidence. Students love having someone who cares, likes and shows interest in their affairs. Children like seeing their parents in the classroom Foster, [27].

Parents were invited to attend many conferences, open days, and celebrations held for their children birthdays or appreciation day. The school leaders allowed parents to volunteer in environmental, health, social workshops. They helped in celebrations and sports programs. Parents brought food, presents and flowers. The school leaders showed interest in the parents' opinions. They appreciated their comments and feedback. After every parent meeting, parents are asked to write their opinions and suggestions in the parent record book.

In sum, the reform plan in the school has established the some pillars of parents' participation in their children's school because parents have sharp insight to critique and comment so reforming is very important to match their satisfaction. 
According to my research, the five school leaders were willing to reform and started to do that by strengthening the relationship with parents but still need to cover more important points. This shift brings with it dramatic changes in what public education needs from principals. They can no longer function simply as carrying out regulations and managing the staff. They have to become leaders of teaching and learning who can develop the mentality of all from students to parents.

The barriers to the parent/family volunteers in school could be resolved if all the parties work together to overcome them by recruiting translators and establishing Arabic and English labs in the school. These labs can improve the languages and clarify the misunderstanding educational information.

\section{Conclusion}

In this fast-paced, technological and advanced information, a great need for highly qualified leaders to lead to a real educational development. As previously stated, expanding the role of parents in the education of their children will have benefits to the children, parents and to the school community. In this school the level of involvement by Emirati parents has increased in recent years, particularly through the encouragement of the principals and the opportunities they have created but still has gaps and needs more efforts. In other words, we can say that the relationship between parents and teachers is changing and also reform planning keep changing. Now it is developing into a more collaborative approach. This allows parents and teachers to understand better what are happening in school. The teachers of this school also encourage, enhance and support parent involvement. They have job satisfaction and good relationship with their students' parents that reflect positively on the school environment. Parents/Family-school collaboration in this school is a cooperative process of planning that brings together school staff, parents, children, and community members to maximize resources for child achievement and development.

In my opinion, when parents participate in their children's school, it will deliver a positive message to the children that the children are very important and valuable to the parents. It also provides the school with a wider range of views from parents of a variety of backgrounds, giving the school a better idea of what the community wants and needs from the school. Through the study, we can see the seeds of learning organization and positive environment. Parents could be an effective tool of successful marketing policy.

This study demonstrates that a culture of family volunteering in school should be learnt and activated because more ideas and efforts will enrich the educational fields and resolve many problems and we can help parents to turn from visitors to partners. I hope this study can add some information towards the importance of parents/families volunteering in U.A.E and how transformational and shared leadership can increase the ways in which parents and community members can volunteer to help in the academic and social achievement of Emirati children. 


\subsection{Recommendation}

Parent involvement is considered to be an important part in educational process because there is an expanding role of parents in the school to improve their children learning. In this research the following approaches are recommended to complete this progress.

Expanding the awareness of the important role of parents: Many families are unaware of the important and positive role that parents play in the emotional, behavioral, physical and cognitive development and wellbeing of their children (Childs Trends Data Bank, [71] and Elias, Zins, Graczyk \& Weissberg,[72]. To resolve the problem of lack of awareness training courses can be held for parents on how they can increase their role. The courses can explain to the parents also what the strategies of the reform plan are and how the school leaders will implement it (Epstein \& Salinas, [73] Parents have to know that schools cannot adequately address the issues of educating children without actively involving the parents and home in the process. Research has begun to map out strategies that after-school and youth development programs use to engage families, including supporting families, communicating and building trust, hiring and developing a family-focused staff, and building linkages across individuals and organizations Kakli et al.,[74]. Such mutual, trusting family involvement relationships can improve the academic adjustment of children (Lopez, Kreider, \& Caspe, [75]. Volunteers may have ideas that could make the program more effective, especially if there is a wealth of experience and expertise of senior populations in the community.

Creating different strategies to encourage parents to take active participation in their children's' school: Parents need to be made more aware that taking a direct interest in what happens at school provides an effective learning environment for their children and leads to improved academic performance McWayne, Hampton, Fantuzzo, Cohen, \& Sekino, [76]. Volunteers can be invited to share a cultural heritage, language, and customs. This is a mechanism for involving educated grandparents in a school. This can be done through a welcoming policy and the appreciation of any parents' efforts. The school leaders have to work to create an atmosphere where parents are respected and welcome. Based on the experiences of (Crew \& Dyja, [77]in urban schools, they believe that the vast majority of parents rich and poor alike want to support their children's learning, but many poor parents do not know how to do it effectively. In the UAE, that parents who do not have a lot of education, need to be encouraged and be taught about how they might help their children at home.

Other strategies for increasing parents' involvement are sending list of needs and opportunities to the home with the students. Also, providing training courses for English medium teachers in U.A.E schools can help teachers to deal effectively, culturally and linguistically with diverse parents. "More attention and resources are neseccsry to support pre-service and in-service training for administrators, teachers, family school coordinators, and other educators in family involvement" (Westmoreland, Rosenberg, Lopez, \& Weiss, [69].

Implementing ongoing assessment strategies: Conducting ongoing assessment is a much needed strategy. The success of any volunteer program is measured with an 
evaluation of whether the goals and objectives of the program have been achieved or not. Ideally, these goals and objectives should be cooperatively established by teachers, volunteers, and administrators. As part of this process, teachers need to acknowledge what is going well, what is not going well and, what should be done differently. Positive points should be emphasized and the weak points should be strengthened. Real progress in family involvement will also require the development of a strategic research, innovation, and evaluation agenda. Conceptions of the role of research and evaluation are changing in major ways with new emphases on innovation, learning, and continuous improvement. In addition, hiring translators and more supervisors will support the success of the reforming plan.

\subsection{Implications for future research}

This study identified the leadership style of a principal in creating a school environment and culture that supports parent involvement. It was conducted to yield an understanding of how one of Emirati school leaders' practices towards parents' involvement contributes to the development of partnership between families and schools. This study provides critical information for parents, teachers, policy makers, and school officials attempting to design and implement parent involvement initiatives in Emirati schools. Although studies attest to the overall benefits of the parents'/family volunteering in school settings, there is a gap in the literature relevant to the U.A.E. context. This study attempted to fill this gap by specifically presenting new data on the effective roles of the parents/family involvement in the school and the leadership style that enhances this involvement. This study is a call for a shift from current education policy which tends to create "random acts of family involvement" Gil Kressley, [78] to a building of more coherent, comprehensive, continuous, and equitable approach to family involvement.

\section{References}

[1] Ferguson, C. (2005). Developing a collaborative team approach to support family and community connections with schools: What can school leaders do? (Strategy Brief).

[2] Castro, J. I. (2004). Promoting leadership development and collaboration in rural schools. In J. H. Chrispeels (Ed.), Learning to lead together, (pp. 327-341). Thousand Oaks, CA: Sage Publications. https://doi.org/10.4135/9781452232416.n13

[3] Dombrowsky,L. (2010). Parents in partnership. A parent engagement policy for Ontario. Ontario: Queen's Printer for Ontario.

[4] Young,K.S (2009).The founding father of the United Arab Emirates. Sheikh Zayed and Arab legend .Korea: Yonsei University press.

[5] Macpherson, R. Kachelhoffer, P. \& El Nemr, M. (2007). The radical modernization of school and education system leadership in the United Arab Emirates: Towards an indigenized and educative leadership. International Studies in Educational Administration, 35(1),6077.Retrived:September15,2012,from http://new.promente.org/files/research/ESPdocs/UAE.pdf

[6] Abu Dhabi Education Council.(2010). Abu Dhabi educational policy agenda. Retrieved March 19, 2012, from Abu Dhabi Education Council: http://www.adec.ac.ae/ 
ADEC $\% 20$ Shared\%20Documents/Publications/ADEC-Agenda $\% 20$ Eng $\% 20 \mathrm{Web} \% 20$ 21Feb\%20For\%20Client.pdf, https://doi.org/10.1093/ww/9780199540884.013.u41768

[7] Fullan, M . (2009). The challenges of change: Thousand Oak, C A: Corwin Press.

[8] Bass B. M. \& Riggio, R. E. (2005). Transformational Leadership, (2nd,ed) Mahwah, NJ: Lawrence Erlbaum Associates.

[9] Senge, P. (2006). The fifth discipline: The art and practice of the learning organization. Revised Ed. New York: Currency/Doubleday.

[10] Bass, B. M. (2008). The Bass handbook of leadership: Theory, research and managerial applications (4th ed.). New York: Free Press.

[11] Bass,B.M. (2011). Transformational Leadership Theory. Study Mode.com. Retrived: April2,2013, from http://www.studymode.com/essays/Bass-Transformational-LeadershipTheory-560776.html.

[12] Bass, B. M., \& Riggio, R. E. (2006). Transformational leadership (2nd ed.). Mahwah, NJ: Lawrence Erlbaum.

[13] Fullan, M. (2010). Motion leadership: The skinny on becoming change savvy. Thousand Oaks, CA: Sage.

[14] Northouse, P.G.(2007) . Leadership theory and practice (4thed.). Thousand Oaks, CA:Sage Publishing.

[15] Díaz-Sáenz, H. R. (2011). Transformational leadership. The SAGE handbook of leadership, 299-310.

[16] Gumusluoglu, L., \& Ilsev, A. (2009). Transformational Leadership and Organizational Innovation: The Roles of Internal and External Support for Innovation. Journal of Product Innovation Management, 26, 264-277. https://doi.org/10.1111/j.1540-5885.2009.00657.x

[17] Abu-Tineh, A., Khasawneh, S., \& Al-Omari, A. (2008). Kouzes and Posner's transformational leadership model in practice: The case of Jordanian schools. Leadership \& Organizational Development Journal, 29 (8), 648-660. https://doi.org/10.1108/01437730810916613

[18] Kouzes, J, M., \& Posner. B, Z. ( 2012). Remember the secret to success in life. In the leadership challenges. Hoboken, NJ: Jossey-Bass.

[19] Anderson, T. D., Gisborne, K., \& Holliday, P. (2006). Every officer is a leader. 2nd ed., Trafford Publishing, Victoria, BC.

[20] Anderson, K. D. (2008). Transformational teacher leadership in rural schools. The Rural Educator, 8-17.

[21] Chew, J. \& Chan, C. C. A. (2008). Human resource practices, organizational commitment and intention to stay. International Journal of Manpower, 29(6), 503-522. https://doi.org/10.1108/01437720810904194

[22] Boaduo, N. Adjei, A. (2009), Parent-community involvement in school governance and its effects on teacher effectiveness and improvement of learner performance. Educational Research and Review Vol. 4 (3), pp. 096-105.

[23] Masumoto, M., \& Brown-Welty, S. (2009). Case Study of Leadership Practices and School-Community Interrelationships in High-Performing, High-Poverty, Rural California High Schools. Journal of Research in Rural Education, 24(9). Retrieved Septemper 15, 2012 from http://jrre.psu.edu/ articles/24-1.pdf .

[24] Chrispeels, J. H. (Ed.). (2004). Learning to lead together: The promise and challenge of sharing leadership. Thousand Oaks, CA: SAGE Publications. https://doi.org/10.4 135/9781452232416.n15

[25] Senge, P. (2006). The fifth discipline: The art and practice of the learning organization. Revised Ed. New York: Currency/Doubleday.

[26] Nsubuga,Y.K.K (2008),Analysis of leadership styles and school performance. ( Doctoral dissertation).Retrieved from 
http://www.nmmu.ac.za/documents/theses/YUSUF\%20K.K.\%20NSUBUGA.pdf (On March4, 2012).

[27] Foster, R. (2005) Leadership and secondary school improvement: case studies of tensions and possibilities, International Journal of Leadership in Education, 8(1):35-52.

[28] Sergiovanni, T. J.(2009).The principalship : A reflective practice perspective (6th ed.).Boston: Pearson. https://doi.org/10.1080/1360312042000299233

[29] Catechism of the Catholic church. (1999). New York, NY: Burns and Oates.

[30] Holy Qur'an. ( Ta-Ha 20:114).

[31] Dearing, E., Kreider, H., Simpkins, S., \& Weiss, H. B.(2006). Family involvement in school and low-income children's literacy performance: Longitudinal associations between and within families. Journal of Educational Psychology, 98, 653-664. https://doi.org/10. 1037/0022-0663.98.4.653

[32] Jeynes, W. H. (2005). Parental involvement and student achievement: A metaanalysis (Family Involvement Research Digest).Cambridge, MA: Harvard Family Research Project.

[33] Midraj, S. M. (2011). Parental involvement and grade four students' Arabic readers achievement. European Journal of Educational Studies 3(2), 2011, 251.

[34] Jeynes, W. H. ( 2011). Parental Involvement Research: Moving to the Next Level, The School Community Journal, 2011, Vol. 21, No. 1, p.10. Retrieved from http://www.adi.org/journal/resources/2011ss_SCJ.pdf.

[35] Colarusso,R,.\& O’Rourke. C.(2007). Special education for all teachers (4th ed). Dubuque, IA: Kendall/Hunt Publishing Company.

[36] Mo, Y., and Singh, K. (2008). Parents' relationships and involvement: effects on students' school engagement and performance. Research in Middle Level Educa-tion Online, 31(10), 111. Retrieved September 22, 2012, from www.nmsa.org/portals/0/pdf/publications/RMLE/rmle_vol31_no10.pdf. https://doi.org/10.1080/19404476.2008.11462053

[37] Kochanek, J.R., Wraight, S., Wan, Y., Nylen, L., and Rodriguez, S. (2011). Parent involvement and extended learning activities in school improvement plans in the Midwest Region. (Issues \& Answers Report, REL 2011-No. 115). Washington, DC: U.S. Department of Education, Institute of Education Sciences, National Center for Education Evaluation and Regional Assis-tance, Regional Educational Laboratory Midwest. Retrieved on November 17, 2012 from http://ies.ed.gov/ncee/edlabs. https://doi.org/10.1 037/e606942011-004

[38] Friedman, B., Bobrowski, P. and Markow, D. (2007 ) Predictors of parents' satisfaction with their children's school, Journal of Educational Administration, Vol. 45 No. 3, pp. 278-288. https://doi.org/10.1108/09578230710747811

[39] Friedman, B.A., Bobrowski, P.E. and Geraci, J. (2006), Parents' school satisfaction: ethnic similarities and differences, Journal of Educational Administration, Vol. 44 No. 5, pp. 47186. https://doi.org/10.1108/09578230610683769

[40] Al Sumaiti, R (2012). Parental Involvement in the Education of Their Children in Dubai. Dubai School of government, Policy Brief No. 30. Retrieved October 27, 2012, from www.dsg.ae/en/.../223201211810458340000.pdf.

[41] OECD, 2010. PISA In Focus \#10, What Can Parents Do to Help Their Children Succeed in School?http://www.pisa.oecd.org/dataoecd/4/1/49012097.pdf.https://doi.org/10.1787/5k9h 362jdgnq-en

[42] Eleanor M. Lemmer, E.M.(2007). Parent involvement in teacher education in South Africa. International Journal about Parents in Education. Vol (1), No. 0, p. 218-229 schools. School Psychology Review, 32, 303-319. 
[43] Anfara, V.A., \& Mertens, S.B. (2008). Varieties of parent involvement in schooling. Middle School Journal, 39(3), 58-64. https://doi.org/10.1080/00940771.2008.11461635

[44] Minke, Kathleen, \& Anderson, Kellie. (2005). Family-school collaboration and positive behavior support. Journal of Positive Behavior Support, 7(3), 181-185. https://doi.org/10.1177/10983007050070030701

[45] Kochanek, J.R., Wraight, S., Wan, Y., Nylen, L., and Rodriguez, S. (2011). Parent involvement and extended learning activities in school improvement plans in the Midwest Region. (Issues \& Answers Report, REL 2011-No. 115). Washington, DC: U.S. Department of Education, Institute of Education Sciences, National Center for Education Evaluation and Regional Assis-tance, Regional Educational Laboratory Midwest. Retrieved on November 17, 2012 from http://ies.ed.gov/ncee/edlabs. https://doi.org/10.1 037/e606942011-004

[46] Al Sumaiti, R (2012). Parental Involvement in the Education of Their Children in Dubai. Dubai School of government, Policy Brief No. 30. Retrieved October 27, 2012, from www.dsg.ae/en/.../223201211810458340000.pdf.

[47] Gems Royal Dubai School. (n.d.) . Retrieved Febrauray 29, 2013, from Month Day, Year, fromhttp://www.gemseducation.com/MENASA/rds0026/contents.php?pageid=2244\&pare ntid $=203$.

[48] Al-Taneiji, S. (2008). Students' views on parental involvement in United Arab Emirates secondary schools. Journal of Educational and Psychological Science, 9 (2), 12-29.

[49] Currie, R.\& and Al Sharif, F.(2005). Parents and teachers working together, Campus Notes. Retrieved Febrauray 29, 2013, from http://gulfnews.com/about-gulf-news/al-nisrportfolio/notes.

[50] Badri, M. A., Mason, S. E., \& El Mourad, T. (2010). Determinants of parent's satisfaction with subjects taught and the effects of school factors, parent's demographics and school's characteristics. The London International Conference on Education (LICE 2010) London, UK - 6-8 August, 2010 Abu Dhabi Education Council Research and Planning Division. Retrieved July 18,2012

from http://www.adec.ac.ae/ADEC\%20Shared\%20Documents/attachments/RnD/Determinants_ of_parents_satisfaction1.pdf.

[51] Yin, R.K. (2003). Case Study Research Design and Methods (3rd ed.) Thousand Oaks, CA: Sage.

[52] Tashakkori, A., \& Teddlie, C. (Eds.). (2003). Handbook of mixed methods in social and behavioral research. Thousand Oaks: Sage Publications. https://doi.org/10. $\underline{4135 / 9781506335193}$

[53] Creswell, J. W. (2012). Qualitative inquiry and research design: Choosing among five approaches. SAGE Publications, Incorporated.

[54] Creswell, J.W. (2011). Mapping the developing landscape of mixed methods research. In A.

[55] Tashakkori \& C. Teddlie ( Ed), SAGE handbook of mixed methods in social and behavioral research (2nd ed.,pp.45-68). Thousand Oaks, CA: Sage. https://doi.org/10.41 $\underline{35 / 9781506335193}$

[56] EdSource. 2008 "Guiding the Growth of California's School Leaders.” Leadership (January/February): 18-21.

[57] Creswell, J. W. (2003). Research design: Qualitative, quantitative, and mixed methods approach. Thousand Oaks, CA: Sage.

[58] Creswell, J. W. (2007). Qualitative inquiry \& research design: Choosing among five approaches $(2 \mathrm{nd}$ ed.). Thousand Oaks, CA: Sage. 
[59] Merriam, S. B. (2001). Qualitative research and case study applications in education. San. Francisco: Jossey-Bass Publisher.

[60] Love , P. (2003). Document analysis. In F. Stage, \& K. Manning (Eds.), Diverse research approaches and methods applied to the college environment.

[61] Patton, M. Q. 2002. Qualitative research and evaluation methods. 3d ed. Thousand Oaks, CA: Sage.

[62] Guthrie, J. W., \& Schuermann, P. (2011). Leading Schools to Success: Constructing and Sustaining High- Performing Learning Cultures. Thousand Oaks, CA: Sage. ISBN: 9781412979016. https://doi.org/10.4135/9781452230580

[63] Opdenakker, Raymond (2006). Advantages and Disadvantages of Four Interview Techniques in Qualitative Research [44 paragraphs]. Forum Qualitative Sozialforschung / Forum: Qualitative Social Research,7(4),Art.11,Retrieved: http://nbnresolving.de/urn:nbn:de:0114-fqs0604118.

[64] Levy, S., Kim, A.H., \& Olive, M.L. (2006). Interventions for young children with autism: A synthesis of the literature [Electronic Version]. Focus on Autism and Other Developmental Disabilities. 21, 55-62. https://doi.org/10.1177/10883576060210010701

[65] Hill, N. E., \& Taylor, L. C. (2004). Parental school involvement and children's academic achievement-Pragmatics and issues. Current Directions in Psychological Science, 13, 161164. https://doi.org/10.1111/j.0963-7214.2004.00298.x

[66] Fullan, M. (November 2006). Leading Professional Learning. The School Administrator.

[67] Marzano, R. J., Waters, T., \& McNulty, B. A. (2005). School leadership that works: From research to results. Aurora, CO: Mid-Continent Research for Education and Learning.

[68] Barbuto, J.E. (2005). Motivation and transactional, charismatic, and transformational leadership: A test of antecedents. Journal of Leadership and Organizational Studies, 11(4), 2640. https://doi.org/10.1177/107179190501100403

[69] Spreitzer, G.M., Perttula, K.H. \& Xin, K. (2005). Traditionality matters: an examination of the effectiveness of transformational leadership in the United States and Taiwan. Journal of Organizational Behavior, 26, 205-227. https://doi.org/10.1002/job.315

[70] Westmorel, H., Rosenberg, H., Lopez, M. E., \& Weiss, H. (2009). Seeing is Believing: Promising Practices for How School Districts Promote Family engagement. Cambridge, MA: Harvard Family Research Project.

[71] Caspe, M. S. (2003). How teachers come to understand families. The School Community Journal, 13(1), 115-131.

[72] Childs Trend Data Bank, 2004. Parental Involvement in Schools. http://www.childtrendsdatabank.org/pdf/39_PDF.pdf.

[73] Elias, M. J., Zins, J. E., Graczyk, P. A., \& Weissberg, R. P. (2003). Implementation, sustainability, and scaling up of social-emotional and academic innovations in public.

[74] Epstein, J., \& Salinas, K. C. (2004). Partnering with Families and Communities. Eduational Leadership, 61(8). p. $12-18$.

[75] Kakli, Z., Kreider, H., Little, P., Buck, T., \& Coffey, M. (2006). Focus on families! How to build and support family-centered practices in after school. Cambridge, MA: Harvard Family Research Project and Build the Out-of-School Time Network. Retrieved from http://www.hfrp.org/content/download/1075/48578/file/focus_on_families.pdf.

[76] Lopez, M. E., Kreider, H., \& Caspe, M. (2004/ 2005). Co-constructing family involvement. The Evaluation Exchange: Evaluating Family Involvement Programs, 10(4), 2-3.

[77] McWayne, C., Hampton, V., Fantuzzo, J., Cohen, H. L., \& Sekino, Y. (2004). A multivariate examination of parent involvement and the social and academic competencies of urban kindergarten children. Psychology in the Schools, 41, 363-377. https://doi.org/10.1002/pits.10163 
[78] Crew, R., \& Dyja, T. (2007). Only connect the way to save our schools. New York: Farrar, Straus and Giroux.

[79] Gil Kressley, K. (2008, August). Breaking new ground: Seeding proven practices into proven programs. Session description from the National PIRC Conference, Baltimore, MD.

\section{$7 \quad$ Authors}

Hazar Hekmat Malluhi an economist and works for the British Institute of Economy and Policy, London, UK (nightengale_m@hotmail.com).

Dr. Nayel Musa Alomran is professor of Science and Technology and pursues interests in law. He works at the Department of Legal Studies, College of Humanities and Social Sciences, Zayed University, Abu Dhabi, UAE (nayel_shaker@yahoo.com)

Article submitted 2019-01-21. Resubmitted 2019-04-03. Final acceptance 2019-05-02. Final version published as submitted by the authors. 